\title{
Governance lessons from public-private partnerships: examining two cases in the Greater Ottawa Region
}

\section{Commonwealth Journal of Local Governance \\ Issue 16/17: June 2015 \\ http://epress.lib.uts.edu.au/ojs/index.php/cjlg}

\author{
Joshua Jebuntie Zaato \\ School of Political Studies \\ University of Ottawa \\ Ontario, Canada
}

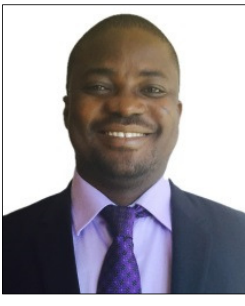

\section{Pierre-André Hudon}

École nationale d'administration publique (ENAP) Montreal (Quebec), Canada

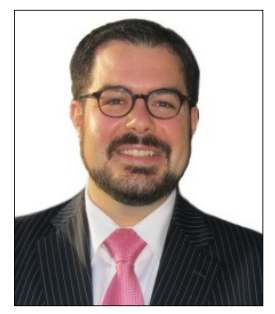

\begin{abstract}
This paper is concerned with studying the administrative and democratic effects of PPP procurement involved in the realisation of two PPP projects in the Greater Ottawa region: Gatineau's RobertGuertin Arena and Ottawa's Lansdowne Park. First, we review the theory regarding PPPs and democratic municipal governance. Second, we propose a normative framework of good governance in the municipal sector, tailor-made to infrastructure matters. Third, we critically analyze the decisionmaking process and contractual agreements of both projects in order to identify key issues regarding infrastructure PPPs in municipalities. We conclude by drawing lessons from the analysis of the two projects and discussing the potential implications of our findings.
\end{abstract}

Key Words: Public-Private Partnerships, democratic governance, value-for-money, public procurement, Ottawa, Gatineau

\section{Introduction}

Public-private partnerships (hereafter, PPPs) are increasingly used as a procurement method for municipal infrastructure. According to their proponents, PPPs generate significantly greater value for money (VFM) than traditional procurement through private sub-contracting and risk-sharing, while still allowing for public control of projects. Nevertheless, many PPP projects do not seem to deliver the results they promise: total costs are often much greater than those estimated, risks are seldom borne by the private partner, and the democratic process often appears to be circumvented in the name of the efficiency. 
The Greater Ottawa region in Canada has recently seen the development of two municipal infrastructures projects - the renovation of the Robert-Guertin Arena in Gatineau and the reconstruction of Lansdowne Park in Ottawa - which seem particularly appropriate as test cases given the tight media scrutiny they faced and the richness of the data available. This paper is therefore concerned with studying the administrative and democratic effects of PPP procurement through the analysis of the contractual agreements and decision-making processes involved in the realisation of both projects.

The paper is structured as follows. First, it reviews the theory regarding PPPs and democratic municipal governance. Second, it will propose a normative framework of good governance in the municipal sector, tailor-made to infrastructure matters. The paper then critically analyzes the decisionmaking process and contractual agreements involved in Gatineau's Robert-Guertin Arena and Ottawa's Lansdowne Park in order to identify key issues regarding infrastructure PPPs in municipalities. It concludes by drawing lessons from the analysis of the two projects and discuss the potential implications of the findings.

\section{PPPs and good governance: a conceptual clarification}

In this section, we propose a conceptual clarification of the theoretical concepts surrounding the study of PPPs. We first present a working definition of PPPs, based on the idea that they are both a management tool and a public policy mechanism. We also propose a normative definition of good governance in the municipal sector, tailor-made to infrastructure matters. We subscribe to the idea that the tools of government are not neutral and that their selection does not constitute a mere "technical" choice of implementation (Lascoumes \& Le Galès, 2006). Rather, we contend that any instrument chosen to implement public policy will, in and of itself, create a certain power imbalance between the parties involved. Because of their contractual nature, this structuring effect of public policy instruments applies very well to PPPs, since they can include various clauses that redistribute the risk and benefits.

\section{PPPs: a definition}

For the purposes of this analysis, PPPs will be defined as "contractual arrangements between a government and a private party for the provision of assets and the delivery of services that have been traditionally provided by the public sector" (de Bettignies \& T. W. Ross, 2004, p. 136). Added to this definition is the caveat that these contractual arrangements require considerable longevity (about 25 years) and complexity in order to distinguish them from other forms of public-private collaboration such as concessions or outsourcing. Typically, PPPs will be undertaken for projects such as roads, bridges, hospitals, sports centres, prisons, etc. Whether they are used as a procurement mechanism or a decision-making and implementation tool, PPPs are expected to secure the economic and financial 
ends of minimizing the on-budget expenditure of governments on public services and infrastructure (Vining and Boardman 2006; Boardman and Vining 2007; Murray 2006; Vining et al 2005). At the same time, they are expected to ensure the production and provision of public services and infrastructure at a lower cost compared to traditional means of producing them (Boase 1999; de Bettignies and Ross 2004; Vining and Boardman 2006). Table 1 below lists the theoretical benefits of PPPs in the municipal sector, according to their proponents.

Table 1 - Benefits of Public-Private Partnerships, according to the City of Ottawa

\begin{tabular}{|c|c|}
\hline $\begin{array}{l}\text { Key Benefits of } \\
\text { P3s for Residents }\end{array}$ & $\begin{array}{l}\text { - } \quad \text { Ability to access new state-of-the-art facilities; } \\
\text { - } \quad \text { Faster design and construction of new facilities; } \\
\text { - } \quad \text { Continued access to programming and services; } \\
\text { - } \quad \text { Projects reflect residents' priorities; } \\
\text { - } \quad \text { Minimizes to stimulate economic growth and employment; } \\
\text { - } \quad \text { Frees up public funds for other core services }\end{array}$ \\
\hline $\begin{array}{l}\text { Key Benefits of } \\
\text { P3s for the City }\end{array}$ & $\begin{array}{l}\text { - } \quad \text { Shares risk and responsibility with private-sector partners; } \\
\text { - } \quad \text { Addresses key issues such as multiple demands, high expectations and } \\
\text { pressure to reduce debts ; } \\
\text { - } \quad \text { Accesses new sources of funds and new specialized skills; } \\
\text { - } \quad \text { Delivers capital projects (buildings and infrastructure) faster; } \\
\text { - Reallocates resources to core areas under government responsibility, thereby } \\
\text { improving the use of assets ; }\end{array}$ \\
\hline $\begin{array}{l}\text { Key Benefits of } \\
\text { P3s for the } \\
\text { Private Sector }\end{array}$ & $\begin{array}{l}\text { - } \quad \text { Steady revenue streams linked to secure contracts; } \\
\text { - } \quad \text { New business opportunities; } \\
\text { - } \quad \text { Potential to build on the expertise of government organisations; } \\
\text { - } \quad \text { Sharing of risks. }\end{array}$ \\
\hline
\end{tabular}

Source: $\underline{\text { http://www.ottawa.ca/business/bids_contracts/p3/about/index_en.html }}$

PPPs are essentially contracts for the long-term provision of goods and services. Typically, a PPP contract will be signed between a public authority and a private entity (usually a promoter or a consortium of many firms, such as banks, contractors, engineers, etc.) and will include the design, building, owning, operation and eventually the transfer (to the public entity) of assets by the private partner (Koppenjan, 2005; Bing, Akintoye, Edwards, \& Hardcastle, 2005). Often, the project will also be financed (at least partially) by the private partner. PPPs rely upon the concept of risk sharing, whereby all risks in the project are contractually allocated to the partner most able to manage them (Bovaird, 2004). Although the ability to actually transfer the risk has been contested in the critical literature on PPPs (Hamel, 2007; Hodge, 2004; Broadbent, Gill, \& Laughlin, 2008; Flinders, 2005; Froud, 2003), it nonetheless remains part of the rhetoric associated to these arrangements, especially in public policy documents. For example, according to the City of Ottawa, PPPs offer the following benefits, detailed in table 1 above. With the theoretical sharing of risks also comes the sharing of the benefits. PPPs generally include contractual clauses that enable the sharing of benefits.

Finally, in complete coherence with one the central tenets of New Public Management (NPM) PPPs are generally enacted through performance (result-based) specifications, instead of process-based requirements, therefore leaving more decisional power to the private partner to design and implement the policies. 
They can therefore be treated as 1) procurement mechanisms (because they usually rely on a public call to tender that usually cover the conception, management, maintenance and sometimes financing) and 2) as public policy instruments (because they constitute a way to decide upon and implement public policies). This acknowledgement of their complex nature will be fundamental to our discussion of the way to observe their effect on good governance.

\section{A normative approach to municipal infrastructure governance}

Many studies have examined the concept of governance from different perspectives. Nevertheless, the concept has remained elusive and difficult to concisely define. Even governance scholars such as Bovaird and Löffler (2009) have argued that trying to define governance "seems to open a Pandora's Box" (p. 8). Farazmand (2004), for instance, describes it through the concept of a chain of network of institutions that seek to blend market-type principles with political ideals. Other studies see governance from an organisational management and performance perspective, and equate it to "how an organisation works with its partners, stakeholders and networks to influence the outcomes of public policies" (Bovaird and Löffler, 2009, p. 6). For the purposes of this study, however, governance will be defined using Olowu's (2002) idea that it should be conceived from a "process perspective with emphasis on rule of law, accountability, participation, transparency and human and civil rights" (p. 4).

These concepts are generic and generally accepted in the literature and in theory as constituting democratic governance (Olowu, 2002; Pierre, 2000; Pierre and Peters, 2000). According to governance scholars, adherents to these democratic processes and principles should be at the very heart of any contractual agreement or relationship between the government and private sector. It can be deduced from this framework that good governance comprise two key criteria. The first deals with the normative democratic aspect of good governance and includes public sector values such as accountability, transparency, public participation, equity and the rule of law. The second comprises managing the public and private interface in a manner that ensures the interest of the public is not sacrificed in the pursuance of VFM objectives. These two criteria are mutually inclusive and should be taken as such.

With specific reference to PPPs, we have divided these two criteria of democratic governance into two categories: administrative (or "contractual") performance, which is more concerned with issues of resource optimisation or VFM, and democratic process, which addresses normative and political questions and concerns. They are categorised in Table 2 below. 
Table 2 - Two facets of good governance

\begin{tabular}{|l|ll|}
\hline $\begin{array}{l}\text { Administrative } \\
\text { Performance } \\
\text { (Value for Money) }\end{array}$ & $\begin{array}{l}\text { Efficiency: The production of the highest output possible } \\
\text { (beneficial effects of public policies) for the lowest quantity of } \\
\text { input (capital, labour, etc.); }\end{array}$ \\
\hline Effectiveness: The ability to meet the set objectives; \\
\hline $\begin{array}{l}\text { Economy: The procurement of goods and services at the lowest } \\
\text { possible cost. }\end{array}$ \\
\hline $\begin{array}{l}\text { Transparency: An easy access to information by all, at all points } \\
\text { during the public policy cycle; }\end{array}$ \\
$\begin{array}{l}\text { Accountability: The necessity for a public policy actors to be held } \\
\text { accountable for their actions and inactions; } \\
\text { Participation: The ability for all stakeholders impacted by a } \\
\text { decision to have their voices heard. }\end{array}$ \\
\hline
\end{tabular}

Based on these normative criteria and in light of our description of the various functions of PPPs, we derive a framework based on table 3 below. This framework has the analytical advantage of capturing the ambiguous nature of PPPs as public policy instruments and the multifaceted reality of PPPs as contractual procurement tools.

Table 3 - Normative framework for evaluating infrastructure governance through Public-Private Partnerships
\begin{tabular}{|l|l|l|}
\hline Aspect of a PPP & $\begin{array}{l}\text { Main Administrative } \\
\text { Concerns }\end{array}$ & Main Democratic Concerns \\
\hline $\begin{array}{l}\text { Contractual Procurement } \\
\text { Mechanism }\end{array}$ & Economy Efficiency & $\begin{array}{l}\text { Rule of Law; } \\
\text { Accountability (hierarchical/ } \\
\text { professional); } \\
\text { Transparency (openness / } \\
\text { publicness). }\end{array}$ \\
\hline $\begin{array}{l}\text { Public Policy Decision- } \\
\text { Making Instrument }\end{array}$ & Effectiveness & $\begin{array}{l}\text { Participation; } \\
\text { Accountability (legal/ political); } \\
\end{array}$ \\
& $\begin{array}{l}\text { Transparency (accessibility / } \\
\text { responsiveness). }\end{array}$ \\
\hline
\end{tabular}

Economy, efficiency and effectiveness are usually considered Value for Money (VFM) criteria, as they ensure that public monies will be spent appropriately (Demirag et al., 2004; Grimsey \& Lewis, 2005). However, it seems important here to stress that economy and efficiency alone are not sufficient to consider a project "a good deal". Indeed, effectiveness, i.e.: the ability to meet public policy objectives, is adamant in reaching good governance from public sector point of view and must not be overlooked. In PPPs, VFM is usually deemed to be present because of two factors: the public sector comparator exercise that is supposed to verify that PPP projects will only be undertaken if they are proven to be better VFM than traditional procurement (de Bettignies \& Ross, 2004), and the classic liberal assumptions that the private sector will always be more efficient than the public sector (Perry $\&$ Rainey, 1988). We find these factors inadequate in determining a comparative efficiency between PPPs and other mechanisms because they are bias towards private consortiums. Secondly, considering the resource and power asymmetries between the public and private consortiums, these two factors will always work to the advantage of PPPs. Finally, the high transactional costs associated with PPPs renders them out of reach to other partiers thereby reducing competition and all its associated and expected benefits. 
It should be emphasised that these VFM criteria are only one facet of what we consider good governance. The democratic process is at the very heart of good governance, as it stems from the public nature of the goods and services produced by public administrations. Mostly, democratic criteria are concerned with ensuring that elected officials and citizens are the real decision-makers and are fighting against the misappropriation of public resources. Accountability, transparency and respect for the rule of law on the other hand are adamant in the battle against misappropriation of public resources and vehicles for good governance. They mostly come as a package and are particularly crucial to PPPs because of their complexity and the need to protect the public interest. Aucoin and Heintzman (2000) for instance stress that, "accountability is a cornerstone of public governance and management because it requires that those who hold and exercise public authority be held accountable" (p.245).

However, accountability has assumed a higher prominence in PPPs' discourse due to the high ethical expectations expected under PPPs in the provision of public infrastructure because of their complexity, costs and life span. This high expectation also emanates from the distrust of politicians and the political process by citizens (Romzek \& Ingraham, 2000; Thomas, 2007; Barberis, 1998).

Similarly, transparency also appears as a major democratic concern in both types of PPPs. Transparency addresses what the OECD (2005) refers to as the open government concept. This concept goes beyond traditional demands for transparency to include accessibility and responsiveness in navigating the interface between the government, private business, civil society organisations, the media and citizens (OECD, 2005). This new and enhanced transparency requirement is particularly relevant and applicable to PPPs because of what is often referred to as non-disclosure provisions in PPPs contracts which prevents the public and other relevant institutions from the ability to scrutinise these PPP contracts. From all intents and purposes, these non-disclosure provisions are expected to prevent the release of contractual details and relevant information that is of interest to the public in order to protect their private interests. This practice however is contrary to the letter and spirits of good governance in general and the open government concept in particular. Furthermore, the accessibility and responsiveness aspect also addresses the service delivery aspect of PPPs especially in areas such as user fees and the citizen/client conundrum. This is because to be responsive and accessible means that citizens should be treated as sovereign and that cost should not be a barrier to accessing public goods and services, PPP or not. It is therefore no coincidence that transparency appears on both the contractual and public policy aspects of PPPs.

Using this framework, we now turn to the analysis of two PPPs in the Ottawa region. 


\section{PPPs in the Greater Ottawa Region}

In this section, we critically examine the failed project of Gatineau's Robert-Guertin Centre1 and the current plans for renovating Ottawa's Lansdowne Park. For these two projects, we study both the contractual arrangements' and the decision-making process's influence on good governance.

\section{Gatineau's Robert-Guertin Centre}

In the spring of 2009, the City of Gatineau decided to rebuild the Robert-Guertin arena - where the Olympiques, a junior-level professional hockey team played all its game - by entering into a PPP agreement with a Consortium composed of a local contractor and the owner of the Olympiques. This decision was taken by the city council after receiving a proposal from the consortium promising renovate and lease the arena to the City for a period of 25 years (once the renovations are completed). The Robert-Guertin arena, built in 1957 , needs to be completely renovated in order to accommodate high-level hockey games (Gatineau, 2010).

In February 2007, a study conducted by the engineering firm Dessau-Soprin analyzed various options for the Robert-Guertin Centre (RGC), including moving to another location, demolishing and building and new arena, renovating the current arena, entering into a PPP contract, etc (Gatineau, 2010; Le Droit, 2007). The report concluded that the best option would be to build a new 6000-seat, two-rink arena on the current site of the Robert-Guertin Centre, financed through a PPP agreement. In the months that followed, the city council voted for a scaled-down project containing only one ice rink, but still using the PPP model.

In April 2008, the City of Gatineau, hired a new Director General, Robert Weemaes, who had previously worked at the City of Repentigny where, amongst other things, he had overseen the construction of an arena using the PPP model. Mr. Weemaes was generally seen as a very pro-PPP municipal manager (Duquette, 2008). Finally, in the spring of 2009, the Consortium proposed a project in which the City would cede, through an emphyteutic lease, the lot on which the RobertGuertin Centre is built. In return, the Consortium would renovate the arena for a cost of $\$ 28 \mathrm{M}$ and lease the renovated building to the City for 25 years (Gatineau, 2010). Table 4, below, summarises the details of the agreement that were leaked to the media.

\footnotetext{
1 The information presented in this case study comes from a series of newspaper articles by Pierre Bergeron, Patrick Duquette and Catherine Lamontagne from Le Droit newspaper, as well as from the City of Gatineau's 2010 Auditor General Report (Gatineau, 2010). The detailed references of all the documents cited can be found in the "References" section of this article.
} 
Table 4 - Contractual characteristics of the Robert-Guertin PPP Project

\begin{tabular}{|c|c|}
\hline $\begin{array}{l}\text { Financial Obligations by } \\
\text { the City of Gatineau }\end{array}$ & $\begin{array}{l}\text { The City must pay, monthly: } \\
\text { - The capital and interest payment on the loan contracted by the } \\
\text { Consortium ( } \$ 28 \mathrm{M} \text { at } 5.25 \%=\$ 167,799 \text { a month); } \\
\text { - Monthly management fees of } \$ 120,000 \text { a month; } \\
\text { - Payments of } \$ 40,000 \text { to a maintenance reserve fund starting at the } \\
\text { beginning of the fifth year; } \\
\text { - Taxes and insurance payments. }\end{array}$ \\
\hline Other Relevant Clauses & $\begin{array}{l}\text { - The reserve fund, although owned by the City, is managed by the } \\
\text { consortium, thus raising the issue of the selection process of the } \\
\text { subcontractors; } \\
\text { - The contract is "net-net-net", which means that all taxes and } \\
\text { insurance are to be paid by the City. This is fairly common in most } \\
\text { commercial real estate leases; } \\
\text { - The City has the ability to renegotiate the terms of the loans; } \\
\text { - A clause enables the owner of the Olympiques to move the team to } \\
\text { another city for a penalty of } \$ 250,000 \text {. }\end{array}$ \\
\hline
\end{tabular}

Source: Contract between the City of Gatineau and 7124358 Canada inc., approved by city council on March 27 ${ }^{\text {th }}, 2009$ (Gatineau, 2009)

On March 27th, 2009, the City Council was asked to vote on the agreement after limited debate at the City Council. The councillors were presented with the preliminary framework agreement only a couple of hours before the vote were called. No public consultations were undertaken and there were no possible modifications to the contract. The urgency of the situation was invoked - the risk of losing the hockey team was alluded to, as well as the decrepit state of the installations (Lamontagne, 2009). It can also be presumed that such urgency was linked to the fact that the mayor was up for reelection on November 1st, 2009 and that signing the contract before the campaign would have been politically very popular (Bergeron, 2009). Upon noticing the growing uproar, the Minister for Municipalities, Regions and Territory Organisation of Quebec, as per her prerogative, put a halt to the project. She cited the need for a call to public tender as a reason to stop the project (Duquette \& Lamontagne, 2009).

\section{The PPP structure and the nature of the contract}

We now turn to an analysis of the governance issues linked to specific clauses of the PPP contract. First, economical procurement is at stake, as there seems to be a fundamental problem with the way the bidding was undertaken. Indeed, in multi-bidder procurement, the lowest cost is deemed to be obtained precisely because of the competition effect between bidders in an unconstrained market. Therefore, in a situation of oligopoly of monopoly (where competition is low or non-existent), prices should be negotiated based on previous experiences or similar projects (Bajari, McMillan \& Tadelis, 2008). In the case of the Robert-Guertin Centre, this was clearly not the case, as the City accepted the only proposal that it received. Questions thus arise regarding how competitive the price paid by the City was. Furthermore, the fact that the loan is contracted by the Consortium - which presumably has a worse credit rating than the City - would mean that the rent payment by City would contain a higher interest component than if the loan had been contracted directly by the City. This could be beneficial if the City was willing to pay a premium to protect itself against financial risk. However, it seems reasonable to think that if the Consortium has financial problem, the risk would immediately be 
shifted back to the City, which would have no other choice to either help out financially the consortium or buy back the arena itself.

Let us also recall that PPPs, like other instruments of public action, tend to induce a power relationship between the actors involved. We contend that some specific issues in this agreement have the effect of shifting power away from the City and toward the Consortium:

- No offsetting benefits for the additional risk incurred by the City. It can be argued that this specific PPP causes greater risk for the City than traditional procurement does, while not providing very little shared benefits. Indeed, traditional procurement would have had the City take control over a number of smaller, fragmented contracts instead of signing one allencompassing contract with a single, not vetted company. Furthermore, the contract includes no profit-sharing mechanism or penalties for underperformance, as would be the case for traditional PPPs;

- Skewed penalties for cancellation. A clause enables the owner of the Olympiques to move the team to another city for a penalty of $\$ 250,000$. This amount can be considered fairly marginal, given the profit expectations of a hockey team in the LHJMQ. This seems unduly risky for the City given the low penalty faced by the owner and the consequences - which would be to leave the City with an empty arena - of such an action for the City;

- Opaque cost structure. The $\$ 120,000$ management seems very arbitrary given the fact that no details were given regarding what it contained. This raises the issue of the different levels of transparency and disclosure that are expected in the public and private sectors, respectively, and of what this implies in terms power imbalance.

Another important aspect of procurement, which touches upon the most basic understanding of the rule of law and of transparency, is the way subcontracts are granted. Indeed, under traditional procurement, any repair to the arena that would cost more than $\$ 50,000$ would need to go through a call to tender process. Under the PPP agreement, the reserve fund (contributed to by the City, but managed by the Consortium) is used to pay for those repairs (Gatineau, 2009). But because it is managed by the private partner, it could be used as a way to circumvent the call to tender process by enabling the Consortium to choose the contractor itself, or to do the work in-house for a price that cannot be determined through competition or negotiation (thus presumably higher). The same point can be made about unionised labourers: PPPs could be used as a way to avoid dealing with the City's unionised workforce by having the Consortium hire the maintenance employees (Duquette, 2009a).

What can be learned from all this? First, that PPP are extremely sensitive to the quality of the contract. PPPs, because they are essentially procurement contracts, run the risk of producing lopsided results if the contract is not written properly from the beginning. Furthermore, because the contracts are typically very long and complex and cover just about every aspect of a project, a small imprecision can have very important consequences regarding risks and benefits, usually to the detriment of the public sector. This also stresses the need for public sector expertise to be on a level playing field with firms that often have a lot of experience in PPPs. Second, that the bidding process 
is of first and foremost importance in ensuring the lowest cost and the best quality, especially in a context where projects are tailor-made to meet the infrastructure needs of a municipality. Third, that there are dangerous democratic consequences of applying a private sector frame of mind to public management, especially with regards to the transparency and accountability requirements.

However, beyond the problematic issues with the very nature of the contract, we contend that there are also democratic problems concerning the decision-making process.

\section{The decision-making process}

Our first observation is related to the hybrid nature of PPPs, as a procurement tool and a decisionmaking mechanism. Indeed, there seems to be a complete blurring of two simultaneous decisions that need to be made: the decision to use PPP as a mode of procurement, and the decision regarding the nature of the project. It could be argued that PPPs constitute only one option for procurement - the other one being traditional procurement - and that, therefore, the same project could be done as a traditional project or as a PPP. This is precisely what happens with PPPs managed at the Quebec provincial level, where the use of PPP procurement must be justified through an exercise called Public Sector Comparator, whereby traditional and PPP procurement are compared and the most economical solution is chosen. Although there are well-known transparency and instrumentalisation issues surrounding this exercise (Rouillard \& Hudon, 2009; Khadaroo, 2008), we feel it nevertheless should be part of an honest public debate over procurement.

In the case of the Robert-Guertin Centre, the Public Sector Comparator was never done. The debate on the nature of project also suffered from being drowned into the debate over procurement and would certainly have benefited from stronger public scrutiny and greater transparency. The "aura of mystery" surrounding PPPs can in part be blamed for this, especially in municipalities whose politicians and civil servants are not too familiar with this mode of procurement. It seems that PPPs are a "buzzword", poorly defined and poorly understood, that make politically-sensitive decisions even more political. The fact that the new Director General, Mr. Weemaes, was initially presented as a person that would help the City undertake PPPs certainly supports the idea that public debate over the relevance and effectiveness of this mode of procurement was skipped (Duquette, 2008).

Our second observation concerns issues of participation. In the case of the Robert-Guertin Centre, there seems to have been an instrumentalisation of the Dessau-Soprin report. The report was indeed the main justification provided by the City for undertaking the project as a PPP. The City also claimed that the report indicated that no company, except for the Consortium was interested in bidding for the project. Nonetheless, when the proposal by the Consortium was made public, two companies (including Dessau-Soprin) indicated that, had a public call to tender been issued, they would have submitted a proposal (Duquette, 2009b). PPP procurement therefore seems to have played a role in 
limiting public participation and debate, by "clouding up" the decision making and by instrumentalizing, through selective information diffusion, expert advice.

Below, the analysis will shift to the second PPP project in the study; the Lansdowne Park redevelopment in Ottawa.

\section{Lansdowne Park at a crossroads}

On 2nd September 2009, staff of the City of Ottawa and a private firm, Ottawa Sports and Entertainment Group (hereafter, OSEG) presented a proposed plan based on a financial partnership to city council. According to the promoters (Ottawa, 2009), the plan:

- Involved the redesign and redevelopment of Lansdowne Park;

- Aimed at developing the historic park into a green, sustainable urban outdoor venue with sports facilities for soccer, football and hockey and serve as a modern meeting, socialising and even commercial point;

- Involved putting to good use an old historic relic and maximising its value for the citizens of Ottawa.

The initial plan gained the approval of city staff and the National Capital Commission (NCC) and was also approved by City Hall but ran into some legal challenges. However, in July 2011, a judge in Ottawa ruled against the Friends of Lansdowne Park, who sued the city to stop the project because they claimed the City of Ottawa acted in bad faith, violated its own procurement by-laws, and illegally favoured OSEG (Superior Court of Justice, 2011). Following the ruling, the City of Ottawa and OSEG have begun work on the almost \$300-million project. How did we get here and what were the real issues between the litigants? And more importantly, what does this project mean for future PPP projects in Ottawa? We examine these questions below beginning with a brief historical review of the project.

\section{Re-examining the Lansdowne Park Project PPP arrangement}

The Lansdowne Park Project (LPP) is premised on a PPP arrangement that is aimed at tapping into private capital for execution of the project. To facilitate and enhance the progress and management of the project, a proposed municipal corporation, to be known as Municipal Services Corporation (MSC), will be created and will be wholly owned by the City of Ottawa (Ottawa, 2009). The MSC will be a shared capital corporation, operate at an arm's length from city council and have an autonomous personality. This independent MSC will then enter into a contract with OSEG for the redevelopment of the park. Under the proposed business model arrangement, the City will transfer its share of the capital and funds for developing the stadium, the arena and the associated cost of the parking lot at a total cost of $\$ 129.3$ million plus the land for up to 30 years to MSC for onward transfer to OSEG (Ottawa, 2009). OSEG on the other hand will provide the other half of the cost of the first phase, estimated at $\$ 125$ million as part of its equity share (OAG, 2009). 
It is also proposed that MSC will enter into a 30 year lease agreement with OSEG to undertake the design, redevelopment, construction and operation of the project. OSEG will set up a fund for maintaining the building in a 'like new' position before transferring it to the city at the end of the 30 years lease period. Thus, prima facie, this proposal represents a win-win PPP for both parties (Ottawa, 2009). The city gets to upgrade and redevelop the park, generate employment and taxes while sharing the costs. OSEG on the other hand gets to partner the city, share the cost, assumes operational responsibilities for 30 years, at the end of which it would have recouped the $\$ 125$ million it invested and made some profits (Ottawa, 2009). This arrangement seems simple enough as a straight business plan between two partners sharing costs, risks and profits. However, a critical examination of the proposed financial arrangements shows this contract to be lopsided, favouring OSEG and disadvantaging the city.

\section{The PPP structure and the nature of the contract}

The entire project is divided into different phases and structured around different financial arrangements between MSC and OSEG:

- The first part is the construction of the stadium and the arena. Under the proposed financial arrangement, $\$ 110$ million in cash comprised of avoided budgetary cost during the construction period (approximately $\$ 8.4$ million) and $\$ 101.8$ million debt will be transferred from MSC to OSEG for the redevelopment of the stadium and the arena.

- The city will therefore virtually contribute to the cost of redeveloping and reconstruction of the stadium and the arena;

- MSC will contribute $\$ 19.3$ million and OSEG will contribute $\$ 17.5$ million for the construction of the parking lot. OSEG will maintain and operate the parking lot;

- OSEG will also invest $\$ 80.1$ million for the construction of 300,000 square feet of retail shops (Ottawa, 2009; OAG, 2009)

Thus, in phase one of the LPP, the Office of the Auditor General (OAG) report on the process indicate that the city will contribute a total of $\$ 119.3$ million while OSEG contributes a total of $\$ 117.2$ million (OAG, 2009). Table 5 below shows the financial contribution from both parties.

Table 5 - Phase 1 Capital Costs (\$ million)

\begin{tabular}{|l|l|l|}
\hline & City (MSC) & OSEG \\
\hline Stadium/Infra./Bldg./Lawn & $\$ 110$ & - \\
\hline Parking Garage & $\$ 19.3$ & $\$ 17.5$ \\
\hline Retail/Cinema/Infra./Lawn & - & $\$ 80.1$ \\
\hline CFL/OHL Franchise Fee/Start-up Costs & - & $\$ 19.6$ \\
\hline Phase 1 Total & $\mathbf{\$ 1 2 9 . 3}$ & $\mathbf{\$ 1 1 7 . 2}$ \\
\hline
\end{tabular}

Source: OAG (2009)

The proposed phase two of the project will see OSEG investing almost $\$ 95$ million for the construction of a residential, office and hotel spaces. In general, OSEG will assume all construction risks associated with the redevelopment of the project. Such risks include design, schedule delays, 
budget overruns, construction defects and quantity estimates errors. However, OSEG will not pay any rent for this investment for 30 years.

Profits from the project will be shared in the form of what experts in an academic study of the proposal refer to as a 'waterfall arrangement' (Lee \& Tiger, 2009). In their study of the project on behalf of the Old Ottawa South Community Association (OSCA), Ian Lee of Carleton University Business School and Michael Tiger, an economist, described the 'waterfall agreement' as the priority ranking of cash flow distribution between the partners in the project. It is a speculative exercise based on projections (Lee \& Tiger, 2009). The formula is a hierarchical arrangement that determines who gets paid, when and how. The current arrangement will ensure that OSEG gets paid first and gets most of the 'water', reduce the speed and volume of the water to the next level and ensures that when it is the city's turn, the speed and volume of the water will be slow (Lee \& Tiger, 2009). Furthermore, under the closed system which considers cash flows from the entire site and not only a single segment, additional net flow will be distributed as per Table 6 below.

Table 6 - Profit Distribution between OSEG and City/MSC

\begin{tabular}{|l|l|l|}
\hline \multicolumn{2}{|c|}{ PROFIT DISTRIBUTION } \\
\hline Level 1 & $\$ 1.5$ million at 2013 & $\begin{array}{l}\text { Annual payment to the City/MSC for life-cycle maintenance of the } \\
\text { new site. }\end{array}$ \\
\hline Level 2 & $\$ 1.6$ million at 2013 & $\begin{array}{l}\text { Annual interest payment of 8\% to OSEG on \$19.6 million in } \\
\text { franchise fees and start-up costs for the CFL and OHL teams. }\end{array}$ \\
\hline Level 3 & Not specified & $\begin{array}{l}\text { Annual principle payments by 2014 to OSEG for 30-year return on } \\
\$ 30 \text { million equity (rate of return not specified). }\end{array}$ \\
\hline Level 4 & $\$ 1.6$ million at 2013 & $\begin{array}{l}\text { Annual interest payment of 8\% to City for return on deemed equity } \\
\text { of \$20 million (value of land). }\end{array}$ \\
\hline Level 5 & Not specified & $\begin{array}{l}\text { Any remaining revenue after Levels 1-4 are met; to be split evenly } \\
\text { between OSEG and City. }\end{array}$ \\
\hline
\end{tabular}

The waterfall arrangement essentially ensures that OSEG gets paid first and more, even though they invested little. It further ensures that the $\$ 80$ million invested by OSEG is a priority in the waterfall arrangement and will be paid first (Lee \& Tiger, 2009). Thus, while the city comes first in the hierarchy of most contributions and has most to lose, it comes last in the sharing of revenue. The waterfall thus makes sure that the private interest is protected, defended and secured before and beyond the public interest even though the public is contributing more for the whole project. Furthermore, the closed financial system ensures that OSEG gets paid on interest in areas like the stadium in which it did not invest. The most intriguing aspect is that under the waterfall arrangement, OSEG even gets paid first in the sectors that only the city invested and has risks. Concomitantly, OSEG will lease the retail shops, hotel and office spaces for 70 years (and not the 30 years stated) and in addition pay no rent for 30 years (Lee \& Tiger, 2009). In short, the city will assume most, if not all the cost while OSEG makes the most profit for a period of 30 years before the city can begin to expect any returns. Both the waterfall arrangement and the closed financial system ensures that the city can only make a profit after OSEG has recouped all its investments and made profits for30 years. If these 
financial arrangements are one sided, there are no guarantees for protecting the city and tax payer in the governance structure of the LPP.

\section{Re-examining the decision-making process}

Under the proposed arrangement, an MSC will be created and empowered as an independent corporation to work with OSEG. As Lee and Tiger (2009) explain, the proposed MSC will be completely independent from City Council after it is formed. That means that there will be no vertical or horizontal accountability once the MSC is formed and the business contract with OSEG signed. Considering all the financial and political risks involved in such a project, the lack of adequate accountability and transparency assurances is both problematic and a blatant disregard for the tenets of good governance expected in a liberal democracy. This is because the only people that will benefit from such an accountability-free arrangement are the private business partners, because once City Council loses its right to hold the MSC accountable, the democratic process is sacrificed. This will mean that city council cannot hold either the MSC or OSEG to account for shirking and other opportunistic behaviour due to information asymmetry inherent in a principal-agent arrangement such as this one (Wallis et al., 2007; Lane, 1996).

Also, the choice of single source funding or the refusal to open up the process to competitive bidding violates federal, provincial and even the City of Ottawa's own policy on public-private partnerships (Lee \& Tiger, 2009). Competition is expected to reduce cost, improve efficiency and create a level playing field for all players. By choosing a single source bid, the city sacrifices its neutrality and compromises the public interest. Such a move creates the impression of a potential conflict of interest between city staff and OSEG. It therefore opens the city staff to accusations of bribery, corruption, nepotism and favouritism in the award of contracts. Such accusations do not only question the legitimacy of the project, it could significantly reduce public confidence, trust and support not only in the project, but also in the entire governance system.

Apart from these accountability deficits, a proposed public consultation process only succeeded in providing very minimal, simplistic and highly inaccurate information to the unsuspecting public. For instance, while the City of Ottawa will only begin to make any returns or dividends after 30 years under the waterfall arrangements, OSEG will begin making profits as soon as the projects commences and profits begin coming in. But this information is not told to the public. Also, before the city can get a single income from this project, OSEG would have fully recovered all its cost despite the disproportionate contributions from the city. Thus, the public consultation process seems like a public relation campaign rather than a commitment to engage, involve and enlist the contributions and by implication support of citizens. Also, another key requirement is that OSEG will bring a CFL and the Ottawa 67s to Lansdowne Park. Yet, even though an integral component of the project is to bring these teams and sporting events to Ottawa, there is no guarantee that they will be there for the 30 year 
period of the lease (Lee \& Tiger, 2009). Therefore, the CFL and the Ottawa 67s team could leave the city and the park after just 10 or even 5 years appearance. Such a key detail however is not presented to the public, de facto shifting a part of the financial risk to the city.

A project of this magnitude has intended and unintended consequences. The intended consequences are the posited claims for the project. These include the redevelopment of the project, the shopping malls, the football and hockey teams, hotel, office and accommodation facilities. While all these seem good, they obscure the unintended consequences which are equally important and deserve equal attention. Some of these unintended consequences include potential traffic deadlock on an already congested Bank street, the concentration of retail shops in the city centre instead of the periphery, potential bankruptcies of businesses on Bank street as all the human traffic will be redirected to Lansdowne Park and could potentially cannibalise businesses and their sales in the downtown core (Lee \& Tiger, 2009). Not presenting these unintended consequences to citizen's smacks of deception, a cover up and not consultation, participation and involvement.

We contend that, as a policy instrument, the current PPP arrangement between OSEG and the City of Ottawa fails because of the nature, magnitude and value of the good governance trade-offs involved in the current arrangement. As we have demonstrated throughout the analysis, these guarantees are either absent or inadequate. This is clearly corroborated by public opinion polls from the feedback on the public consultations that were supposed to inform, engage and get the support and approval of residents. A Nanos Opinion Research indicated that about half of the residents polled (49.6\%) were ambivalent to the project. A further $22.5 \%$ of residents were completely against it while only $18.7 \%$ percent were for it (Cook, 2009). While it will be a dereliction of duty and irresponsible leadership to base public policies simply on public opinion, we think that these results adds extra value to our argument that the project does not have the support of citizens because of the convoluted nature of the project, the numerous unanswered questions and the good governance deficits involved.

\section{Discussion and conclusion}

In this section, we draw lessons from the analysis of the two projects and discuss the potential theoretical implications of our findings. Both the Robert-Guertin Centre and the Lansdowne Park projects serve as fairly typical, real-life cases of municipal infrastructure projects done through PPP procurement. As such, they can serve as a basis for critical examination which could, in term, lead to a better understanding of the governance issues surrounding PPP procurement. Our verdict is that from both a contractual procurement mechanism and as a public policy tool, the Gatineau and Ottawa PPPs perform rather poorly. This poor performance has to do both with the nature of the PPP agreements, as well as the contingent environment in which the projects were developed. As in most public policy matters, success (and failure) is conditioned both by the effectiveness of the tools used, but also by the context and the way in which they were used. These lessons therefore should not 
constitute general claims about PPPs but, rather, observations concerning two specific cases that can be used as starting point to better understand this governance phenomenon.

If the relative efficiency (time- and process-wise) of both procurement efforts seems to indicate greater performance, we cannot disregard the fact that they were done without a call to tender - which in turn has impact on the ability to secure economic procurement. From a democratic perspective, the absence of competition is illegal for projects of this magnitude and contributes to a lack of openness and publicness, both of which are essential components of transparency in procurement.

As public policy mechanisms, the two PPPs seem to be aligned fairly well with public policy needs (both projects were fairly popular with the general public), but the way they were structured renders political accountability difficult: Gatineau's project was hardly debated by city council while Ottawa's project is governed through an agency that is at arm's length from the municipal government. Furthermore, the very logic behind PPPs, in keeping with one of the most frequent criticism made to NPM, makes accountability difficult by essentially privatizing not only implementation, but also decision making.

The way in which both projects were undertaken highlights many important findings concerning the administrative and democratic effects of PPP procurement. It is to these findings that we turn next.

\section{PPPs and administrative performance}

Administrative performance can be observed by proxy through the criteria of efficiency, effectiveness and economy, and tries to ensure VFM. Based on the analysis above however, we are in a position to state that neither contractual agreement guarantees the cities of Ottawa or Gatineau VFM. First, when we consider the competition effect, it is easy to conclude that both cities are probably left worse off because of the single-bidder process. Indeed, they both could have gained better VFM either through open competitive bidding or direct public procurement.

Second, VFM issues arise regarding the risk and benefit sharing. Indeed, both contracts do not guarantee an adequate sharing of benefits (because of the lopsidedness of the "waterfall scheme" for Ottawa, and because of specific clauses in the contract for Gatineau), even if risk-sharing is used as the justification for the very existence of a PPP. Furthermore, the non-disclosure clauses in the agreement, which make restricts proper risk evaluation, are particularly problematic, given that risk sharing, which is touted as one of the relative advantages of PPP over traditional means of procurement, is impeded by the inability to properly evaluate risk.

Third, regarding the issue of effectiveness (i.e.: the ability to meet public policy objectives), it seems relevant to wonder if the neighbourhood-wide negative impacts of the Lansdowne Park project -such as the negative impacts on surrounding businesses and on traffic levels- might just not outweigh the 
benefits. This highlights the very fundamental contradictions that arise when trying to combine a micro-level, private sector mindset geared toward short/medium term profitability and project-based management with a macro-level, public sector concern for city-wide objectives and long-term societal benefits.

\section{PPPs and the democratic governance process}

The democratic conduct of procurement is observed through the criteria of public participation, accountability and transparency. First, let us notice the blurring of the decision-making induced by the use of the PPP. Indeed, there seems to have been no debate regarding the procurement mechanism, and the debate seems to have concentrated on the project itself. However, given the well-known issues concerning PPPs, a diligent and open democratic debate should have considered the relevance and the trade-offs of using this mode of procurement.

Second, in both projects, electoral concerns seem to play an extremely important role in shaping the public debate, enabling the various actors to invoke the importance of "getting this deal done before the elections". The sensitivity of PPP to electoral concerns, perhaps even more so than traditional procurement due to the magnitude of the projects, has negative effects on the democratic process.

Third, the deliberate distortion of details and the secrecy surrounding final contractual obligations in Lansdowne Park and, to a lesser extent, the Robert-Guertin Centre have a clear effect on transparency and public accountability, but also on the ability of citizens to participate actively in the public debate.

Finally, the closeness of the two municipalities and impending elections in both municipalities which served as policy windows and avenues for political activity and opportunism, arm us with enough evidence to proceed and make informed and educated pronouncements and determinations of the potential fate of the project.

In light of these case analyses, we cannot but agree with Flinders (2005), who mentions that "PPPs represent a Faustian bargain in that forms of PPP may deliver efficiency gains and service improvements in some policy areas but these benefits may involve substantial political and democratic costs" (p. 216). But we also note that in order for these efficiency gains to exist, PPP procurement needs to be done in a way that is respectful of:

- the normal municipal procurement process, which involves public call to tenders, a concern for the economic acquisition of goods and services and the respect of the rules and regulations of purchasing;

- the normal policy-making process, which requires the involvement of public policy actors in the planning, decision-making, and implementation of any given project, as well as the ability to hold those actors accountable for the decisions they make. 
We also lament the fact that efficiency gains are too often seen as a trade-off to democratic principles, when in fact they should be seen as two sides of the same coin. One cannot therefore "sacrifice" accountability and transparency in the name of greater efficiency and effectiveness, because true effectiveness (i.e.: the ability to meet public policy objectives) would include democratic concerns as an end in themselves.

\section{References}

Aucoin, P. \& Heintzman, R. (2000) "The Dialectics of Accountability for Performance in Public Management Reform," in B.Guy Peters and Donald J. Savoie (eds) Governance in the 21st Century: Revitalizing the Public Service, Montreal and Kingston: McGill-Queen's University Press. doi: http://dx.doi.org/10.1177/0020852300661005

Bajari, P., McMillan, R., \& Tadelis, S. (2008). «Auctions Versus Negotiations in Procurement: An Empirical Analysis" Journal of Law, Economics, and Organisation, 1-28.

Barberis, P. (1998) “The New Public Management and a New Accountability" Public Administration, Vol.76, pp451-470. doi: http://dx.doi.org/10.1111/1467-9299.00111

Bergeron, P. (2009, April 2). Robert-Guertin au cœur de la campagne. Le Droit, 13.

Bing, B., Akintoye, A., Edwards, P. J., \& Hardcastle, C. (2005). "The allocation of risk in PPP/PFI construction projects in the UK”. International Journal of Project Management, 23(1), 25-35. doi: http://dx.doi.org/10.1016/j.ijproman.2004.04.006

Boardman A. E. \& Vining, A. R., (2007) "Can P3s Contribute to the Upgrade of Canada's Asia-Pacific Trade Infrastructure?" UBC P3 Project Working Paper. Infrastructure Canada,

Boase, J., (1999) "Beyond Government? The Appeal of Public-Private Partnerships". Canadian Public Administration. Vol.43, No.1, pp.75-92. doi: http://dx.doi.org/10.1111/j.1754-7121.2000.tb01561.x

Bovaird, T. (2004). "Public-Private Partnerships: from Contested Concepts to Prevalent Practice". International Review of Administrative Sciences, 70(2), 199-215. doi: http://dx.doi.org/10.1177/0020852304044250

Bovaird, Tony and Löffler, Elke (2009) "Understanding Public Management and Governance" in Bovaird, Tony and Löffler, Elke (Eds) Public Management and Governance, $2^{\text {nd }} E d$, London: Routledge

Broadbent, J., Gill, J., \& Laughlin, R. (2008). "Identifying and controlling risk: The problem of uncertainty in the private finance initiative in the UK's National Health Service”. Critical Perspectives on Accounting, 19(1), 40-78. doi: http://dx.doi.org/10.1016/j.cpa.2006.04.006

Cook, M. (2009, November 6). Stadium survey results tell council to 'just do it'. The Ottawa Citizen.

de Bettignies, J., \& Ross, T. W. (2004). "The Economics of Public-Private Partnerships". Canadian Public Policy / Analyse de Politiques, 30(2), 135-154. doi: http://dx.doi.org/10.2307/3552389

Demirag, I., Dubnick, M., \& Khadaroo, M. I. (2004). "A Framework for Examining Accountability and Value for Money in the UK's Private Finance Initiative". Journal of Corporate Citizenship, (15), 63-76. doi: http://dx.doi.org/10.9774/GLEAF.4700.2004.au.00008

Duquette, P. (2008, April 4). Gatineau présente son nouveau directeur général. Le Droit, 6.

Duquette, P. (2009a, April 3). Des employés perdraient leur boulot. Le Droit, 6.

Duquette, P. (2009b, March 25). Une troisième firme s'immisce dans le débat. Le Droit, 2.

Duquette, P., \& Lamontagne, C. (2009, May 12). Retour à la case départ pour Guertin. Le Droit, 3.

Farazmand, Ali (2004) "Sound Governance in the Age of Globalisation: A Conceptual Framework" in Farazmand Ali (Ed) Sound Governance: Policy and Administrative Innovations, London: Praeger.

Flinders, M. (2005) "The Politics of Public-Private Partnerships" The British Journal of Politics \& International Relations, 7(2), 215-239. doi: http://dx.doi.org/10.1111/j.1467-856X.2004.00161.x

Froud, J. (2003). “The Private Finance Initiative: risk, uncertainty and the state”. Accounting, Organisations and Society, 28(6), 567-589. doi: http://dx.doi.org/10.1016/S0361-3682(02)00011-9

Gatineau. (2009, March 27). Conclusion d'un protocole d'entente avec 7125348 Canada Inc. et Les Olympiques de Gatineau Inc. Direction générale.

Gatineau. (2010). Rapport annuel 2010 du vérificateur général. Office of the Auditor General of the City of Gatineau. 
Ghere H. R. (2001), "Probing the Strategic Intricacies of Public-Private Partnerships. The Patent as a Comparative Reference", Public Administration Review. 61-4. doi: http://dx.doi.org/10.1111/0033-3352.00048

Grimsey, D., \& Lewis, M. K. (2005). “Are Public Private Partnerships value for money?: Evaluating alternative approaches and comparing academic and practitioner views". Accounting Forum, 29(4), 345-378. doi: http://dx.doi.org/10.1016/j.accfor.2005.01.001

Hamel, P. J. (2007). Les partenariats public-privé (PPP) et les municipalités : au-delà des principes, un bref survol des pratiques. Groupe de recherche sur l'innovation municipale (GRIM), INRS Urbanisation, Culture et Société.

Hodge, G. A. (2004). "The risky business of public-private partnerships". Australian Journal of Public Administration, 63(4), 37-49. doi: http://dx.doi.org/10.1111/j.1467-8500.2004.00400.x

Khadaroo, I. (2008). "The actual evaluation of school PFI bids for value for money in the UK public sector". Critical Perspectives on Accounting, 19(8), 1321-1345. doi: http://dx.doi.org/10.1016/j.cpa.2007.05.001

Koppenjan, J. (. F. (2005). "The Formation of Public-Private Partnerships: Lessons from Nine Transport Infrastructure Projects in The Netherlands" Public Administration, 83(1), 135-157. doi: http://dx.doi.org/10.1111/j.0033$\underline{3298.2005 .00441 . x}$

Lamontagne, C. (2009, March 28). Et le contrat va... aux Olympiques! Le Droit, 3.

Lane, J.-E. (1996) "Public Sector Reforms: Only Deregulation, Privatisation and Marketisation"? in Lane, Jan-Erik (ed) Public Sector Reform: Rationale, Trends and Problems, London: Sage

Le Droit (anonymous author) (2007, February 6). Le nouvel aréna serait confié au privé. Le Droit, 3.

Lee I. \& Tiger M. (2009) “Analysis of Lansdowne Park Development Plan” Sprott School of Business, Ottawa: Carleton University.

Olowu, Dele (2002) "Governance, Institutional Reforms and Policy Processes in Africa: Research and Capacity-Building Implications" in Olowu Dele and Sako Soumana (Eds) Better Governance and Public Policy: Capacity Building for Democratic Renewal in Africa, Bloomfield: Kumarian Press Inc.

Office of the Auditor General (2009) Audit of The Lansdowne Park Proposal Process: Ottawa, Canada

Ottawa (2009) "Lansdowne Partnership Plan: The Transformation of Lansdowne Park" Retrieved on 06/11/2009 from: http://www.ottawa.ca/residents/public_consult/Lansdowne_partnership/report_sept02_en.html

Perry, J. L., \& Rainey, H. G. (1988) "The Public-Private Distinction in Organisation Theory: A Critique and Research Strategy" The Academy of Management Review, 13(2), 182-201. doi: http://dx.doi.org/10.5465/AMR.1988.4306858 and http://dx.doi.org/10.2307/258571

Pierre, Jon (2000) "Introduction: Understanding Governance" in Pierre, Jon (ed) Debating Governance: Authority, Steering and Democracy, Oxford: Oxford University Press. doi: http://dx.doi.org/10.1145/345107.345109 and http://dx.doi.org/10.1007/978-3-0348-8968-1 1

Pierre, Jon and Peters, Guy (2000) Governance, Politics and the State, Houndmills: Palgrave Macmillan.

Romzek, B. S. \& Ingraham P. W. (2000) "Cross Pressures of Accountability: Intiative, Command and Failure in the Ron Brown Plane Crash” Public Administration Review, Vol.60, No.3 doi: http://dx.doi.org/10.1111/0033-3352.00084

Rouillard, C., \& Hudon, P. A. (2009). Le partenariat public-privé : Un instrument d'action publique au coeur des réformes administratives et de la dérive managerielle de l'État québécois. Économie et solidarités, 41(1).

Vining, Aidan R., \& Boardman, Anthony E., (2006), "Public Private Partnerships in Canada: Theory and Evidence". UBC P3 Project Working Paper. Infrastructure Canada,

Vining, A. R., Boardman, A. E., \& Poschmann, F. (2005) "Public-Private Partnerships in the US and Canada: There Are No Free Lunches" Journal of Comparative Policy Analysis, Vol.7, No.3, pp.199-220. doi: http://dx.doi.org/10.1080/13876980500209363

Wallis J. L., Dollery B. \& McLoughlin L. (2007) Reform and Leadership in the Public Sector: A Political Economy Approach. Cheltenham: Edward Elgar

Superior Court of Justice (2011) Friends of Lansdowne Inc. v. Ottawa (City), 2011 ONSC 4402 Court File NO: 10-49352, Ontario Canada. 